\title{
Recording and sorting the diploma thesis file, 2008 - 2018, from the Greek postgraduate program in Cultural Studies: Semiotics and Communication
}

\author{
Ntonou Petroula \\ University of Western Macedonia, Greece \\ Foufa Papada 5, Florina \\ 53100, Greece
}

\begin{abstract}
The postgraduate program of Cultural Studies: Semiotics and Communication of the University of Western Macedonia of the Preschool Department lasted ten years, starting in 2008 and ending in 2018. During this time there are recorded historical data, narratives, conferences, a large number of professors and students who took part, as well as all the diplomatic work that was done (162). In this study, we record and analyze the titles of the diploma thesis that are traced throughout. The methods and theoretical schemes that are chosen are related to archival research of the postgraduate program, applying the leximetric and thematic analysis.
\end{abstract}

Keywords: recording, archives, semiotics

\section{Introduction}

The Hellenic Semiotic Society deals with the study and dissemination of semiotics in Greece. Semiotic is the scientific area that studies in depth all the phenomena of civilization in today's societies, but also in societies of the past, as point systems. Objectives of the semiotics study are, among other things, the daily behavior, the meanings of the gestures and the way of dressing, the structures of poetry and literature, the way the music, the painting and the other arts communicate, the messages emanating from the theater, cinema and the media, as well as the experiences from architecture and in general the built space. The HSS is a member of the International Semiotic Society (IASS-AIS, http://iass-ais.org) and participates in its processes with two national representatives at the IASS Executive Committee and a representative of the Balkan Association for Semiotic Studies, who are entitled voting (http://hellenicsemiotics.gr/).

The subject of this postgraduate thesis is part of the completion of the postgraduate curriculum entitled Cultural Studies: Semiotics and Communication, which belongs to the Educational Sciences, of the University of Western Macedonia of the Preschool Department. This is a research that is not based on an earlier one as it relates to the sorting and recording of the archive of diploma theses that have been implemented since the start of the postgraduate program in 2008 until its expiration in 2018 for the feedback and evaluation of the program, ending in 2019. and highlighting gender, status, and thematic variables identified. The methods and theoretical forms chosen are for archival research, leximetric and thematic analysis. The Research Materials composed a) from the Government Gazettes (2008 to 2017), b)from the Recording of the open interview by the founding members(Papoutzis Lazaros), c) The Thematic Analysis of the Interview and d) The Thematic Classification of the Titles Selected by students and teachers. The postgraduate program was founded on the occasion of the conference held in Florina in 2006-2007 (Government Gazette 1572 / B / 6-08-2008) by the Hellenic Semiotic Society, with the main rapporteurs Alexandros Lagopoulos and Karin Boklund. A second occasion is the innovation for that time, establishment of a graduate program in Semiotics and refers to a field unexplored by the data of the time, especially for the Pedagogical Departments.

The transmitters of the postgraduate program are the professors who support specialties and participate in in cognitive subjects in a) Pedagogy, b) Social and Cultural Studies, c) Media and Communication, d) Urbanism / Architecture, e) in English Literature, in feminist studies and queer issues. The total number of artists and experts participated is 11 and the resulting specialties: Musician, poet, composer, photographer, sculptor, painter, theatrologist. Different sciences cooperated with the Hellenic Semiotic Society and created this new postgraduate program. The students and graduates of the department have contributed to diffusion the concept of Semiotics in a wider context, while many of them have used it as a contraption in their work in areas such as a) journalism, b) communication, c) graphic design, and d) education. Many participations of graduate students identified in schools, meetings, summer schools and conferences, not only in Greece but also at a global level. Some of them concerned cities and countries such as: a) Sozopol of Bulgaria, b) Sofia, c) Italy, d) Tarto, e) Torino, g) Helsinki, and h) Finland. Also important are the collaborations recorded: a) with Ero Tarasti (former world president of the global semiotic society) and b) with Cyprus and the Visual Semiotics Lab. 
The total number of professors registered is 90 and cognitive fields are: History, Psychology, Statistics, Cultural Studies, Pedagogy, Theatrical Education, Modern Greek theater, Linguistics, Law, Graphic Design, Painting, Film, Sculpture, Educational politics, Music, Sociology, Literature, Social Anthropology, Architecture, Mathematics, Urban Planning, English Literature, Informatics, Printing, Business Administration, Literature, Literature, Philosophy, Russian Literature, Rhythmic Education, Marketing, Musicology and Composition, Dance and Kinetics, Special Education. As far as the teachers' biological sex are concerned, 34 women and 56 men arise, while geographically attended by teachers from Bulgaria, England, Finland and Italy. The conferences that took place are total 54. Quantitatively and geographically there are 18 Greek conferences, 4 European conferences, 32 international conferences arise. Interdisciplinary and group work and studies also emerged and promoted one of the objectives of the postgraduate program for interdisciplinarity.

\section{Methodology}

We attended the archival research: "Archives are those evidence that accumulate by physical process at any time in the course of an activity, public or private, and therefore maintained for use - reporting under the supervision of the persons responsible for the activities or their successors" (Jenkinson, 1980)."Historical archives are the evidence of public or private organizations that have been judged worthy of maintenance for study and research and which have been deposited or selected for filing in an archive establishment" (Shellenberg, 1956). "The archives are the yarn of the social fabric of human interaction and offer: proof of the activities and interactions of human relationships and information on the relationships of people, organizations, occurrences and places" (McKemmish, 2000). We have implemented thematic analysis (thematic analysis), which attempts in a systematic way to detect, to organize and understand and understand patterns of meaning ("themes") within a set of elements and thus to provide cognitive access to collective significances and experiences (Braun \& Clarke, 2006).

We also combined the application of leximetric analysis, because it is about counting the nounsand adjectives and is a contraption of analysis of the research material in the field of grammar and the syntax of titles that making small narratives.

The narrative according to Eco (1982), is a material from linguistic signs of semiotic suspension, signifier and signified. It is a way of involving the linguistic elements of the exemplary axles of narrative with the constitutional axles in order to give forms to the signifier and the signified. Thus, the reader will be able through the contrasts, alternations and substitutions of the axles to understand the material as a narrative that will pass through time. The narrative should be combined with plot, the way the reader perceives and knows the myth. The plot consists of smaller narratives that incurthe myth and through the description give liveliness, purpose and content to the narrative. The myth of narrative contains and derives ideologically and politically significants - elements that reflect the social cohesion from which the author derives the content of the myth, or there are elements that restrict him.

The adjustment of leximetry to a narrative, aims at the analysis of grammar and syntax in relation to the political and ideological content. The survey of place names, national names and surnames in this research, apart from identifying the structural elements and content of the narratives we are consider, also identifies the rhetorical elaboration of speech.

The process of analyzing principles, derived in the context of a qualitative research, is associated with an interesting and demanding chain of decisions that the researcher is called upon to take. These decisions have to do with the choice of the specific analytical approach to be attended, as well as with a range of explicit and inexplicit ontological, epistemological and methodological assumptions to be adopted during the analytical process (Tsiolis, 2015).

There are several approaches to analyzing quality elements, which have different theoretical and epistemological endpoints. These approaches are distinct from each other both in relation to their objectives and in their processes and techniques they apply. The researcher chooses a qualitative analysis approach based on the theoretical position he adopts, the type of research questions he has formulated and the type of material he has produced. In all of these approaches, we can incorporate thematic analysis, content analysis and empirically ground on theory. These approaches can be adopted by researchers starting from different theoretical positions and setting different research objectives.

As far as thematic analysis is concerned, we attempt in a systematic wayto understand meaning standards ("themes"), within a set of elements, and in this way to be produced cognitive access to collective significances and experiences concerning the choices of students and professors. 


\section{Research Material}

\subsection{Titles of Diplomatic works}

\begin{tabular}{|c|c|}
\hline 1 & $\begin{array}{l}\text { "Clovers, Thieres and Cannons ..." European Football Team Logo: A Historical, Sociological and } \\
\text { Semiotic Reading" }\end{array}$ \\
\hline 2 & "Football and juvenile subcultures: A case study of fans of ARIS Thessaloniki" \\
\hline 3 & "Danae Stratigopoulou (1913-2009): Life and Work, Contribution to the History of Women" \\
\hline 4 & "Elias Byzantis (1910-1980) store inscriptions in Florina, a contribution to local history" \\
\hline 5 & $\begin{array}{l}\text { "Historical facts and fiction in the Greek cinema for the Civil War: The Troupes, The Hunters, The } \\
\text { Times of the Storm, ... - Soul Deep, Knit Red Thread, (1975-2010)" }\end{array}$ \\
\hline 6 & $\begin{array}{l}\text { "Family stories of mixed marriages: case studies of mixed marriages of Catholic Orthodox in } \\
\text { Thessaloniki during the period } 1980-2010 "\end{array}$ \\
\hline 7 & $\begin{array}{l}\text { "Visual workshop, Second Primary School of Palaia Thessaloniki (1998-2010), case study: design and } \\
\text { aesthetic stages" }\end{array}$ \\
\hline 8 & "Students film and filming. Classification of film material of Secondary Education (2008-2010)" \\
\hline 9 & "Representations of women in modern Greek photography" \\
\hline 10 & s in the Varoshi neighborhood of Florina: Photos and life stories (1850-1960)" \\
\hline 11 & "Gender stereotypes in print advertising: a longitudinal study of wom \\
\hline 12 & "Simon Norfolk: Photojournalism as a Topography of Destruction" \\
\hline 13 & "Evaluating the pages of the Greek Parliament parties. Creating questionna \\
\hline 14 & "Greek State Tourist Advertising (GOT). Semiotic analysis of posters" \\
\hline 15 & "Powerful weblogs: Design and Semiotic Description" \\
\hline 16 & "Semiotic approach to Kostas Sfika's film $<$ Metamorphosis $>"$ \\
\hline 17 & their social choices: education, work, social pla \\
\hline 18 & "Students of Fine Arts Florina paint the pl \\
\hline 19 & "The drama of the trauma: The Civil War \\
\hline 20 & "Students and athletics: Opini \\
\hline 21 & "Class validity and Class Diversity in the Greek Musical of the 1960s" \\
\hline 22 & "Croco producers: History C.D.S. (COOPERATIVE DE SAFRAN / CROCO \\
\hline 23 & "Linguistic and visual material in the "Civil Press" (KKE version)" \\
\hline 24 & "Mapping of the site: Spatial and Historic significants, Students fifth and Sixth $\mathrm{F}$ \\
\hline 25 & "Russian proverbs for marriage: interlingual translation, values and meanings" \\
\hline 26 & s and Applica \\
\hline 27 & "School mathmanual of C' Primary school: Semiotic representations of the values of cult \\
\hline 28 & "Historical research: renaming settlements in the Florina area at the beginning of the 20th \\
\hline 29 & $\begin{array}{l}\text { "Semiotic analysis of school manual. The case study of manual 'Entrepreneurship \& Development' of } \\
\text { B' Lyceum" }\end{array}$ \\
\hline 30 & "Significants and signifiers in T. Adorno's work on music" \\
\hline 31 & study of printed advertisements of the Greek press:The s \\
\hline 32 & "Semiotic and Cinematic Music: The Cas \\
\hline 33 & $\begin{array}{l}\text { "Semiotic and school manual: Case study of religious manual of C' primary school and Analytical } \\
\text { Program" }\end{array}$ \\
\hline 34 & $\begin{array}{l}\text { "Semiotic analysis of past papers in the English language. Case Study of Cambridge Michigan } \\
\text { University Issues" }\end{array}$ \\
\hline 35 & $\begin{array}{l}\text { "Families of musicians and self-taught instrumentalists in Florina (beginning of the 20th century until } \\
\text { today)" }\end{array}$ \\
\hline 36 & $\begin{array}{l}\text { "The historical evolution of the development of the sciences and Technology, 11th-20th Century: } \\
\text { Geographic investigation" }\end{array}$ \\
\hline 37 & $\begin{array}{l}\text { "Seeking the image of the Greek in the years of 1821: Case study of language and visual texts of } \\
\text { children of sixth class of Primary Education in the history lesson" }\end{array}$ \\
\hline 38 & n the Frankfurt School to Postmodernism - The Case of Popular Music" \\
\hline 39 & "Wedding and Significant Practices: The Vlachs of Vlasti Case" \\
\hline 40 & chess in primary education, $\mathrm{w}$ \\
\hline
\end{tabular}




\begin{tabular}{|c|c|}
\hline & udy in Florina" \\
\hline 41 & $\begin{array}{l}\text { "Semiotic analysis of children's clothing catalogs. Case study of companies: Lapin House, Alouette, } \\
\text { Benetton" }\end{array}$ \\
\hline 42 & "Soviet posters from the collection of Sergio Gregorian (1918-1921), aesthetic and historical analysis" \\
\hline 43 & "College of Hellenic guidance of Florina: Recording the history of the society" \\
\hline 44 & "The concept of Democracy in Article 16 of the Constitution" \\
\hline 45 & "Family businesses in the traditional settlement of Nymfeo today: Cas \\
\hline 46 & $\begin{array}{l}\text { "Semiotic Analysis of Images in the Presentation of Cultural Characteristics. Case study of Greek } \\
\text { teaching manuals as a Second Language GEIA SAS1 \& 2" }\end{array}$ \\
\hline 47 & "Routes to the Goumenissa Communities" \\
\hline 48 & $\begin{array}{l}\text { "Representations of Civil Conflict and Ideas in the Political Cartoons of Archelaus (1945-1947) - } \\
\text { Semiotic Readings and Didactical Approaches" }\end{array}$ \\
\hline 49 & $\begin{array}{l}\text { "Feminism and Advertising: Investigating gender stereotypes in Pantene's \#whipit campaign } \\
\text { (LABELS AGAINST WOMEN: Do not Let Labels Hold You Back)" }\end{array}$ \\
\hline 50 & $\begin{array}{l}\text { "Representations of Civil Conflict and Ideas in the Political Cartoons of Archelaus (1945-1947) - } \\
\text { Semiotic Readings and Didactical Approaches" (2) }\end{array}$ \\
\hline 51 & "Art therapy. Visual Arts, Dramatherapy, Music Therapy: Explanatory and Semiotic Approach" \\
\hline 52 & "PIXAR characters: Semiotic a \\
\hline 53 & $\begin{array}{l}\text { "Gender and Cinematic representation: Racial projections and Discrimination in Disney Cartoon } \\
\text { Movies" }\end{array}$ \\
\hline 54 & "The kind of science fiction in cinema in the 21 st century, topics, representations, ideologies" \\
\hline 55 & "Stereotypes of the two genders in the rebetiko subculture (1900-1952)" \\
\hline 56 & "Media and Politics: The referendum of 5th July 2015 through the headlines of the newsp \\
\hline 57 & $\begin{array}{l}\text { "A map of Semitic through postgraduate studies in the specific field of knowledge. Classifications- } \\
\text { thematic-methods" }\end{array}$ \\
\hline 58 & $\begin{array}{l}\text { "By capturing the crisis. An Interpretative Approach of Painting and verbal expressions of Students of } \\
\text { the 6th Primary School for the Economic Crisis in Greece" }\end{array}$ \\
\hline 59 & $\begin{array}{l}\text { "The handsome and the ugly man in the paintings of early and early school children. Identities, } \\
\text { stereotypes and social representations" }\end{array}$ \\
\hline 60 & $\begin{array}{l}\text { "The image of the child in the modern cartoon. The case of the cartoonist KYR (Ioannis } \\
\text { Kyriakopoulos) [1972-2015]" }\end{array}$ \\
\hline 61 & "The child in street art - Graffiti. Optical representations of childhood" \\
\hline 62 & $\begin{array}{l}\text { "Quantitative and qualitative research - 2nd generation immigrants in Greece attending Greek } \\
\text { universities and schools" }\end{array}$ \\
\hline 63 & "The image in the modern Greek fairy tale (2010-2016). Semiotic and pedagogical analysis" \\
\hline 64 & $\begin{array}{l}\text { nd culture through educational activities. Case study of a non-profit } \\
\text { tiada"'” }\end{array}$ \\
\hline 65 & h rights education" \\
\hline 66 & 1: Investigating \\
\hline 67 & "The Representation of Childhood in Traditional Song - 19th to the Beginning of the 20th Century" \\
\hline 68 & $\begin{array}{l}\text { "Gender stereotypes and social representations in preschool age. Case study: contradictory images and } \\
\text { interpretations of two fairy tales" }\end{array}$ \\
\hline 69 & $\begin{array}{l}\text { "Investigation of the way" musical culture "is formed by the students of the University of Western } \\
\text { Macedonia in Florina" }\end{array}$ \\
\hline 70 & d Learning, Education through the Arts. Didactic and Pedagogical Approaches" \\
\hline 71 & $\begin{array}{l}\text { "Gender Representations in the Illustration of the school manual at Greek Language of the sixth class } \\
\text { primary School" }\end{array}$ \\
\hline 72 & $\begin{array}{l}\text { "The phenomenon of school violence and intimidation in the film narrative - Case study: the film In a } \\
\text { better world (2010)" }\end{array}$ \\
\hline 73 & "The operation of the musical narrative in 'Politika Kitchen' in the historical context of the era" \\
\hline 74 & "The Exodus of Mesolongi: Semiotic Analysis of Tables and Texts" \\
\hline 75 & $\begin{array}{l}\text { "Semiotic Analysis of the International Convention on the Rights of the Child and proposals for its } \\
\text { implementation" }\end{array}$ \\
\hline 76 & "Art \\
\hline
\end{tabular}




\begin{tabular}{|c|c|}
\hline 77 & sots \\
\hline 78 & The Loubok Model: The Russian Tradition in Patriotic Propaganda of World War I" \\
\hline 79 & $\begin{array}{l}\text { "Respect for the environment as a value in children's painting - Semiotic analysis of environmental } \\
\text { ethics in children's painting" }\end{array}$ \\
\hline 80 & "Class stereotypes in women's dress in the last century" \\
\hline 81 & $\begin{array}{l}\text { "The Educational Screenshot of Greek School Life over the years: Pedagogical and Socio-Cultural } \\
\text { Components" }\end{array}$ \\
\hline 82 & "Technologically supported, narrative search for geo-cultural information in a e Twinning program" \\
\hline 83 & "The teacher's communication skills to tackle school violence" \\
\hline 84 & "Socio-economic status of parents and school leakage of Roma students: The case of Droserou Xanthi" \\
\hline 85 & $\begin{array}{l}\text { "School manuals and pictures: the case study of the religious book of the sixth class of Primary } \\
\text { School" }\end{array}$ \\
\hline 86 & "Student and teacher representations in music lessons in Attic red-figure vessels" \\
\hline 87 & "Representations of Greekness and Language Messages in Cosmote (2010-2018) Packet Adver \\
\hline 88 & "Representations of People in Art Works: International Non-Violent Movements 1950-1970" \\
\hline 89 & $\begin{array}{l}\text { "Archival Research at Women's Counseling Centers in Western Macedonia: Emphasizing gender } \\
\text { counseling" }\end{array}$ \\
\hline 90 & "Photos documents for the Greeks of the City, historical analysis" \\
\hline 91 & $\begin{array}{l}\text { "Semiotic analyzes and good practices at school" Journey to contemporary Greek music Case study G. } \\
\text { Stavrianos " }\end{array}$ \\
\hline 92 & $\begin{array}{l}\text { "Psychological Analysis of the Illustration of the School Manual," Social and Political Education ", } 6^{\text {th }} \\
\text { class of Primary School. Cognitive and emotional response of students" }\end{array}$ \\
\hline 93 & "Representations of superheroes in films for the period 2001-2015" \\
\hline 94 & $\begin{array}{l}\text { "Organization and Functionality of Educational Programs of Museums: Case Study of the Benaki } \\
\text { Museum Animation Program" }\end{array}$ \\
\hline 95 & ions of Greek High School Students fo \\
\hline 96 & $\begin{array}{l}\text { "Sports and Doping: Student's perceptions of the phenomenon as identified through the use of } \\
\text { cartoons" }\end{array}$ \\
\hline 97 & "Rom musicians and music as an identifier. The case of Iraklia in Serres, in the modern era " \\
\hline 98 & $\begin{array}{l}\text { "Professional choices of Greek elementary school pupils: The family and wider social context of their } \\
\text { choices" }\end{array}$ \\
\hline 99 & "Soci \\
\hline 100 & "Refugee Documentaries: Testimonies on why refugees have left their homelands" \\
\hline 101 & $\begin{array}{l}\text { "Volunteers in Creative Employment at Refugee Host Centers: Their Social Profiles and Their } \\
\text { Motivation" }\end{array}$ \\
\hline 102 & $\begin{array}{l}\text { "The cultural other, as shown in lullabies of the book" The most beautiful lullabies of the world " } \\
\text { Identity and diversity. Multiculturalism and multimodality. Exploiting the Material in a Cultural } \\
\text { Program of Primary Education" }\end{array}$ \\
\hline 103 & "Beers of Greek origin: Socioeconomic analysis of their main labels (2016)" \\
\hline 104 & "Refi \\
\hline 105 & $\begin{array}{l}\text { "Music as a tool in teaching mathematical motifs: An application to pupils of the First class of Primary } \\
\text { School" }\end{array}$ \\
\hline 106 & $\begin{array}{l}\text { "The Social Semiotic Approach to Solving Mathematical Problems in Primary School Students with } \\
\text { Autism Spectrum Disorders" }\end{array}$ \\
\hline 107 & "The project in Education: Entrepreneurship and Leisure" \\
\hline 108 & $\begin{array}{l}\text { "Semiotic sociocultural theory (Radford) and its applications in the field of educational-learning } \\
\text { process" }\end{array}$ \\
\hline 109 & $\begin{array}{l}\text { "Speech and Authority - SYRIZA's example: Possible shifts in the speech of Alexis Tsipras before and } \\
\text { after January 25, 2015" }\end{array}$ \\
\hline 110 & zainst Erdogan. A comparative study" \\
\hline 111 & philosophy of hum \\
\hline 112 & "Theoretical Approaches and Communication Methods in Choosing a career" \\
\hline 113 & "The influence of the family on the management of communication crises in school" \\
\hline 114 & "The administration of the educational process in the schools of Droseros Xanthi thr \\
\hline
\end{tabular}




\begin{tabular}{|c|c|}
\hline & he teachers" \\
\hline 115 & $\begin{array}{l}\text { "Children's Literature in the early childhood education. Case Study: 'The Little Prince' by Antoine de } \\
\text { Saint Exupery" }\end{array}$ \\
\hline 116 & "Sociology at School: Semiotic Analysis of the School manual of the $3^{\text {rd }}$ high school class" \\
\hline 117 & "Bouzouki in Greek Music Schools and his Greekness: Zeibekiko of Evdokia, a case study" \\
\hline 118 & "The Costumes of the superheroes in the Watcmen Comic. A Semiotic Research" \\
\hline 119 & "The role of education in the citizen of the future. Ken Robinson's video case study" \\
\hline 120 & $\begin{array}{l}\text { "Professional development and assumption of professional roles in the Primary School. Semiotic } \\
\text { analysis of the cross-curricular activities of the school manuals of the Greek language course " }\end{array}$ \\
\hline 121 & "Semiotic Analysis of Comics: The Case of Carl Marx" \\
\hline 122 & "The Pretty and the Beast: Semiotic Analysis of the Cinematic Narrative for Children" \\
\hline 123 & $\begin{array}{l}\text { "Libraries of the Municipality of Thessaloniki as places for education and entertainment for children. } \\
\text { Educational programs for children 8-12 years of age five-year 2012-2017. Case study" }\end{array}$ \\
\hline 124 & $\begin{array}{l}\text { "60 Years State Orchestra of Thessaloniki, Leadership and Administration: Archival Research and } \\
\text { Oral History" }\end{array}$ \\
\hline 125 & "Vulnerable groups in cinema: case study of cinematographic works for autism" \\
\hline 126 & "The Theater in Education as a way of teaching values, Eleni Euripides in Secondary Education" \\
\hline 127 & $\begin{array}{l}\text { "The sorcery in Ancient Greece: Curses and adultery. Semiotic analysis of the adultery at the } \\
\text { Archaeological Museum of Pella" }\end{array}$ \\
\hline 128 & $\begin{array}{l}\text { "Bibliographic surveyfor the study of QUEER STUDIES in English bibliography (2000-2017): } \\
\text { Researches in Greece" }\end{array}$ \\
\hline 129 & "Healing springs of Eleftherwn Kavalas ZA Zachos: Vision and creation" \\
\hline 130 & "Music in Cinema: The \\
\hline 131 & "Semiotic Analysis of the Historical Monuments of Veria " \\
\hline 132 & $\begin{array}{l}\text { "Greece as a new homeland: Studying the views of refugee children from Syria, Iraq and Afghanistan } \\
\text { on Greece and the notion of the homeland" }\end{array}$ \\
\hline 133 & "YES, We CAN of will.i.am: Music Video or Political Propaganda?" \\
\hline 134 & $\begin{array}{l}\text { "Religious encounter in Thessaloniki (15th century - 21st century): Places of worship and museum } \\
\text { education" }\end{array}$ \\
\hline 135 & "Music, Sound and Sound Effects at Jurassic Park" \\
\hline 136 & $\begin{array}{l}\text { "Semiotic analysis of visual images through children's sketches of Greek students for the refugee } \\
\text { child" }\end{array}$ \\
\hline 137 & $\begin{array}{l}\text { "Semiotic Analysis of Political Optical Symbols of the far-Right Political Space: Case Study of the } \\
\text { Xrisi Avgi Party" }\end{array}$ \\
\hline 138 & $\begin{array}{l}\text { "Semiotic analysis and comparative study of the "Cross-curricular curriculum (DEPPS, 2014) with } \\
\text { the" Detailed program of Pre-school Education (3-6 years old) "(2016)" }\end{array}$ \\
\hline 139 & "Teaching to refugees: An evaluation of teachers' experience" \\
\hline 140 & $\begin{array}{l}\text { "Language practice and attitudes towards the native language and the language of the host country to } \\
\text { second-generation migrants in Greece" }\end{array}$ \\
\hline 141 & "Teachers and Lifelong Learning: Investigation Teachers' Views on Lifelong Learning" \\
\hline 142 & $\begin{array}{l}\text { "Herbert Marcuse's "One-Dimensional Man" in Giorgos Lanthimos's "Astakos": A Sociological } \\
\text { Approach to an Eclectic Affinity" }\end{array}$ \\
\hline 143 & "The posters of the Thessaloniki Film Festival: a \\
\hline 144 & ommercial a \\
\hline 145 & "Images of Disability in Greek Children's Literature" \\
\hline 146 & "Administration of multiculturalism at school" \\
\hline 147 & "Down syndrome optics in cinema" \\
\hline 148 & $\begin{array}{l}\text { "The Museum as a means of education and training of the child. The study of the Museums of Florina - } \\
\text { The Museum Education in Gymnasium Children " }\end{array}$ \\
\hline 149 & "Representations of ecclesiastical and religious issues in the newspaper "Voice of Florina" 1960-1985" \\
\hline 150 & ipts based on real stories" \\
\hline 151 & "Mainstream Queer Cinema: A Socio-semiotic Approach" \\
\hline 152 & $\begin{array}{l}\text { "The Role of a Creative Movement Program in Relationships } \\
5^{\text {th }} \text { class of Primary School. An experimental approach " }\end{array}$ \\
\hline
\end{tabular}




\begin{tabular}{|l|l|}
\hline 153 & "Education and social exclusion of children with chronic diseases. The case of schools in hospitals " \\
\hline 154 & "Woman and Sexual Realization in Print Advertising: Researching their Attitudes and perceptions" \\
\hline 155 & "The Semiotic Analysis of the Short Film "PROFITEROL" by CHRYSANTHI KARFI-KOI" \\
\hline 156 & "The aspects of the nursery teachers on Visual Art in Preschool Education" \\
\hline 157 & $\begin{array}{l}\text { "The professional stress of primary school teachers (teachers and nursery teachers) in an agrotouristic } \\
\text { area during the economic crisis. The example of Argolida" }\end{array}$ \\
\hline 158 & "Music Notation Issues and Didactical Methodology in Violin and Viola" \\
\hline 159 & "Pangritio and Zanneio: Primary education schools. Archival Historical Research" \\
\hline 160 & "How public-school teachers perceive and interpret educational inequalities" \\
\hline 161 & $\begin{array}{l}\text { "The role of culture in advertising - a comparative semiotic analysis of selected online advertising from } \\
\text { Greece and Poland" }\end{array}$ \\
\hline 162 & "Semiotic analysis of the creation / rotation of the corporate identity of a tourist product" \\
\hline
\end{tabular}

1.2. Indicative analysis of all material

$>\underline{1^{\text {st }} \text { sample: }}$

"Clovers, Thieres and Cannons ..." European Football Team Logo: A Historical, Sociological and Semiotic Reading. Significant: Three phrases with dominantly nouns without a verb, with two subjects (Logo, Reading), in plural and singular. Adjectives are used for determinations and properties as historical, sociological and semiotic Reading.

So, it results as interpreting the field of sociology of sport.

$>\mathbf{2}^{\text {nd }}$ sample:

Football and juvenile subcultures: A case study of fans of ARIS Thessaloniki. Significant: Two phrases with dominantly nouns without a verb, with three subjects (Football, subcultures, of fans), in plural and singular. Also determined without verb and the method (case study). Adjectives are used for chronological determinations (juvenile) and properties, roles attributed to the noun (of fans) as predicates (of ARIS, Thessaloniki).

So, it results as interpreting the field of sociology of sport in a local national field

$>$ 每 ${ }^{\text {rd }}$ sample:

Danae Stratigopoulou (1913-2009): Life and Work, Contribution to the History of Women.Significant: a famous woman in singular, as a biography from the music world: so, it results as interpreting the feminist historical narrative in national field

$>\quad 4^{\text {th }}$ sample:

Elias Byzantis (1910-1980) store inscriptions in Florina, a contribution to local history. Significant: Two phrases with dominantly nouns without a verb, with two subjects (inscriptions, history), in plural and singular. Adjectives are used for local determinations (in Florina) and properties.

So, it results as interpreting the field of history in local and national field.

\section{$5^{\text {th }}$ sample:}

Historical facts and fiction in the Greek cinema for the Civil War: The Troupes, The Hunters, The Times of the Storm, ... - Soul Deep, Knit Red Thread, (1975-2010). Significant: Onephrase with dominantly nouns without a verb, with one subject (War), in singular. Adjectives are used for chronological determinations (Civil, 1975-2010) and properties as historical facts.

\section{So, it results as interpreting the field of history in cinematography in the national field.}

\section{Results- Discussion}

The thematic that arise from the whole of the material, are those of visual culture as advertising, cinema, music and visual arts, local history, history of education and issues of racism and gender diversity.

Gender and class variables appear to penetrate into the most tasks and geographic specifications identified relate to places, nations, microscale, but also in European and international bibliography, both with field studies and bibliographic analyzes. The Cultural Studies developed a special sub-section of Visual Culture Studies, in which emphasize this postgraduate, because it is based in the unprecedented importance of depiction and optical technologies in modern society and deals with all kinds of visual information, its connotations, pleasures and consumption, including all optical technologies, from oil painting to the internet. 
The Social Semiotic of Visual Communication deals with the study of images within their social context and provides a detailed and clear method of analyzing connotations arising from constitutional relations between people, places and objects depicted in the images.

These connotations are described as representations, regarding the modality or the perceived plausibility of the images, as interacting (the images do something for or for the viewer) and synthesis (such as placement of images and text in specific ways). The images are analyzed either to capture the reality or as evidence of how their creators (re) constructed reality, as traces of prejudice, ideologically colored interpretation. The issue of "recording" versus "construction" arises from the nature of the images, especially when some of them contain both elements and require a method of analysis sensitive to both categories.

Advertising images are 'constructions' and the analysis aims at their deconstruction. Content analysis is also often and combined with semiotic: requires at least two different groups of elements for the purpose of comparison and in addition, each of these groups needs to include a sufficiently large number of similar images in order for the groups to be representative and statistically adequate. However, any method of analyzing optical material provides a fairly wide range of defined image characteristics and they are associated with specific connotations and / or communication results. The combination of content and semiotics analysis in the image and in the media has already been implemented. The social semiotic of visual communication includes the description of the semiotics resources: what can be said and done with images and how can things that people say and do with images can be interpreted?

Semiotic tried to study cultural artifacts and practices of any kind based on unified principles, at best giving some consistency to the study of communication media and cultural studies. While the semiotic analysis was widely applied to literary, artistic and musical works, it was also applied to the decoding of a wide variety of popular cultural phenomena. This helped to encourage a serious study of the popular culture.

Another variation of the semiotic is that of Foucault, emphasizes the "results of dialogic practices" (Tagg 1988, 22). It is certainly fair to note that many of the criticisms of semiotics took the form of self-criticism of those who practiced it. The theoretical literature of semiotics depicts a continuous effort by many semiotics to capture the impact of new theories on their own semiotic view. In addition, modern apologists have written that there is nothing new in emphasizing the social dimension of semiotic. The roots of social semiotics can recur to the first theorists. Saussure himself (1974) referred to semiotics as "science that studies the life of points in society", while the notion of notation as a process is central to Peirce's thought. However, it must be recognized that the emphasis on the social dimension of semiotic is relatively recent and is not yet apparent at the center of semiotic practice.

Semiotic is not, it never existed, and it seems unlikely to ever become an independent academic department.It is now widely regarded as a way of analyzing texts of cultural forms (Deacon et al., 1999, 135). Contrary to Deacon's (a.m.) theoretical approaches and predictions, it is clear that in epistemology of the 21 st century, Semiotic is now approaching a wide range of scientific objects and is not used only for the deconstruction and analysis of texts. It combines and is counted on equal terms with subjects of humanities, arts and culture, education and strengthens its methodological tools, supplements in terms of triangulation studies and researches of young researchers.

In the above context, the Semiotic methodological tools have been successfully applied for a decade in the Postgraduate Program of Education Sciences: Semiotic and Communication, approaching a variety of subjects and specialties of researchers - rapporteurs and students, which ended up applying the models taught and transferring them accordingly to their working lives. Ultimately, this is the clear pursuit of a postgraduate program that will mutate knowledge into a way of working, lifestyle - culture and perception.

\section{Reference List}

Braun, V., \& Clarke, V. (2006). Using thematic analysis in psychology. Qualitative Research in Psychology, 3 (2), p. 77-101.

Deacon, David, Michael Pickering, Peter Golding \& Graham Murdock. (1999). Researching Communications: A Practical Guide to Methods in Media and Cultural Analysis. London: Arnold, p.135.

Eco, U. (1982). I simiologia tis kathimerinis zois. Athina\&Thessaloniki: Malliaris- Paideia.

Jenkinson, Hilary. (1980). "The English archivist: A new profession"at Alan Sutton (ed), selected writings of sir Hilary Jenkinson, Alan Sutton, Gloucester, p.258.

McKemmish, S. (2000).Isagogi sta arxeia kai ta arxeiaka programmata. At: J.Ellis (Ed), I Diaxeirish twn Arxeiwn. Athina: Elliniki Arxeiakh Etaireia, Typwthutw/Giorgow Dardanos.

Saussure, Ferdinand de. ([1915] 1974). Course in General Linguistics. London: Fontana/Collins. 
Schellenberg, Theodore R. (1956). Modern Archives: Principles and Techniques. Chicago: University of Chicago Press.

Tagg, John. (1988). The Burden of Representation: Essays on Photographies and Histories. Basingstoke: Macmillan.

Tsiolis, G. (2015). Analysi poiotikwn dedomenwn: dilhmata, dynatothtes, diadikasies. AtG. Pyrgiwtakis\&Chr. Theofilidis (Ed) Ereunhtikh Methodologia stis Koinwnikes Episthmes kai sthn Ekpaideush. Symvoli sthn episthmologikh theoria kai thn ereunhtikh praxi. Athina: Pedio. P. 473-498. 